\title{
ТОM \\ Liberalists and data-solutionists: redefining expertise in Twitter debates on coronavirus in Finland
}

\author{
Esa Väliverronen, Salla-Maaria Laaksonen, Mikko Jauho and \\ Piia Jallinoja
}

\begin{abstract}
Based on recent accounts of the sociology of expertise, we analyse the public contestation and expansion of expertise in the context of COVID-19. During the epidemic, the expertise of the Finnish Institute for Health and Welfare (THL), became increasingly contested. By exploring Twitter discussions concerning the actions of THL during the first months of the epidemic from January to mid-June 2020, we analyse the main motivations and arguments in this public contestation as well as the alternative forms of expertise proposed by the critics. We focus particularly on two forms of criticism arguing for what we call networked expertise: liberal crowdsourcing supporters and data-solutionists presenting alternative epidemiological models.
\end{abstract}

Keywords

Public perception of science and technology; Public understanding of science and technology; Science and media

DOI

https://doi.org/10.22323/2.19050210

Submitted: 30th June 2020

Accepted: 26th August 2020

Published: 30th September 2020

\footnotetext{
"The number of COVID-19 experts in social media is growing day by day. The situation is worrying." (Finnish stand-up comedian and journalist Jukka Lindström on Twitter, 14 March 2020).
}

Introduction

"The coronavirus outbreak is making expertise great again", an op-ed in the Washington Post [Tharoor, 2020] claimed in mid-March 2020. The columnist argued that the popular anti-expertise movement would now calm down. However, we are not convinced about this prognosis. At least in the Finnish context, we have witnessed an increasing contestation of expertise. At the same time, this contestation is taking new forms and is strengthened by social media platforms on which challengers and counter-experts gather and form networks.

The paradox of expertise in late modern society was formulated by Helga Nowotny [2000, p. 6]: “(N)ever has scientific expertise been so prevalent and 
indispensable before, while being embattled at the same time". Nowotny argued that parallel changes in the decision-making structures and in the knowledge production system have diminished the authority of scientific expertise but at the same time have increased the context-dependency of expertise in public life. This development has further contributed to a wider social distribution of expertise, as different actors from various backgrounds have made claims to expertise. And while expert knowledge has become such a highly prized political resource in decision-making, scientific knowledge and expertise have become increasingly disputed and challenged in public discourse.

The COVID-19 epidemic has again made this contested nature of expertise visible. There is an immediate, practical need for more effective communication to mitigate the pandemic, save lives and protect society's capacity for action. Because the crisis evoked a state of emergency, there was a pressing need for accurate knowledge and sound expertise. This created space for a competitive marketplace of expertise and expert knowledge. And it soon became evident that the COVID-19 epidemic was not just a health issue, dealt with by epidemiologists and other health specialists, but it affected almost every aspect of society, culture and the economy, creating a need for many kinds of expert knowledge and advice on how to react and adapt to the changing situation.

Based on recent accounts of the sociology of expertise, we are dealing with an expansion of expertise [e.g. Collins and Evans, 2007; Jasanoff, 2004]. We suggest that in the corona crisis, a new type of expertise was actively promoted - 'networked expertise' — based on crowdsourcing, open knowledge and data science.

During the corona crisis, the Finnish established health expertise became increasingly contested. This public questioning of expertise was particularly intense on social media platforms like Twitter. Well-known Finnish stand-up comedian and journalist Jukka Lindström summed up the situation in his widely shared tweet on 14 March 2020: "The number of COVID-19 experts in social media is growing day by day. The situation is worrying."

Especially the Finnish Institute for Health and Welfare (THL), which is mainly responsible for advice on the control of the epidemic, became increasingly contested. In the beginning of the epidemic, THL was criticized for underestimating the COVID-19 disease and acting too slowly. Later, major points of contention were THL's policy line supporting mitigation, which was heavily criticized by advocates of suppression, and the transparency of THL's epidemiological models. The various actors involved in these criticisms promoted alternative forms of expertise and more open and dialogical forms of communication.

In this article, we analyse how the expertise of THL was contested in public debates on COVID-19. We do this by exploring social media discussions concerning the actions and publicity of THL during the first months of the epidemic from January to mid-June 2020. Our empirical focus is on Twitter, which has become the most central arena for public, political discussions and debates in Finland, particularly for actors who aim to influence political decision making or challenge the authorities [Nelimarkka et al., 2020; Ojala, Pantti and Laaksonen, 2019]. Globally, 
Twitter has grown to be an important arena also for science communication [e.g. Jahng and Lee, 2018], and particularly during the COVID-19 crisis it has provided researchers, politicians and citizens all over the world an important platform for sharing and discussing information on various aspects of the pandemic [Chen, Lerman and Ferrara, 2020]. It is used, for example, to disseminate pre-prints and early versions of COVID-19 studies as well as evaluating them. Thus, Twitter has provided a forum, where new research, expert opinions and policy recommendations are shared and debated.

We analyse the main motivations and arguments in this public criticism as well as the alternative forms and sources of expertise proposed and represented by the critics. We direct our attention to two forms of criticism arguing for what we call networked expertise: liberal crowdsourcing supporters and data-solutionists presenting alternative epidemiological models. There was also a third form of criticism advocating for the authoritarian strategies adopted in China and elsewhere instead of the THL's national prevention strategy. However, it did not involve an alternative form of expertise.

Analytical perspective: the expansion of expertise and the role of media
The media have become an important arena where struggles over the symbolic legitimacy of expert authority take place and where scientific experts increasingly must compete for public recognition of their expertise, authority and credibility. Recently, the cultural authority of science and science-based expertise has been challenged to the extent that the present time has been termed the post-truth and post-factual era. Paradigmatic examples of this era, the Brexit vote in the U.K. and the 2016 presidential elections in the U.S., are called "a loud vote against expertise" [Sismondo, 2017]. The post-truth discourse is presented in books like The Death of Expertise [Nichols, 2017] arguing for increasing ignorance, a despising of expertise and political polarization.

However, the position of science-based expertise is more complex than some of these assessments suggest. First, for some time, scientific expertise has been more prevalent and indispensable than ever before but at the same time constantly embattled, as mentioned above [Nowotny, 2000, p. 6]. Second, it is empirically debatable whether and to what extent public trust in science has actually declined [see Smith and Son, 2013; Castell et al., 2014]. Indeed, national surveys show that although many are skeptical towards particular applications of science and technology, such as genetically modified foods or stem cell research, trust in scientific institutions is not declining [e.g. Finnish Science Barometer, 2019; National Science Foundation, 2018]. Third, new disruptions are also taking place within academia, and new alliances between researchers and those challenging established academic institutions are being formed.

In late modern societies, this trust in expert institutions has been challenged and sometimes even replaced by various competing regimes and discourses [Giddens, 1991; Bildtgård, 2008]. The authority of institutionalized forms of scientific expert advice and expert 'establishments' has been subject to contestation, for example in the cases of vaccines [e.g. Blume, 2006; Blume, 2017; Kata, 2012] and healthy eating [e.g. Gunnarsson and Elam, 2012; Jauho, 2016], by social movements as well as by ordinary lay people. 
This criticism of the public health establishment has become a common feature of public debates on health risks and disease prevention in Finland as well. As regards food, national nutrition recommendations are constantly targeted by critics [Jauho, 2016], and various nutrition coaches promote their own dietary solutions, which often contradict the messages of the public health establishment [Jallinoja, Jauho and Mäkelä, 2016].

Researchers in science and technology studies (STS) have noted for some time that expertise is evolving beyond that of traditional technically and professionally certified elites. On the one hand, proponents of the normative theory of expertise have argued against the decline of public trust in science and scientific experts. According to them, both scholars and citizens should focus more on who the experts actually are and how to recognize them, in terms of what kinds of abilities social actors really possess [Collins and Evans, 2007]. On the other hand, those in favour of a relational theory of expertise have criticized the normative theory in presenting expert knowledge as something fixed and given. Proponents of this relational theory view expertise more as a social attribute. Experts in society are identified not only on the basis of the specific knowledge they possess but also in their capacity as institutionally constituted parts of larger regimes [Jasanoff, 2004], their role being subject to constant public negotiation. The credibility of experts is also a relational concept, subject to constant negotiations between actors in particular situations. The debate between proponents of the normative and relational theories of expertise has been fierce in STS scholarship. However, it is not necessary to treat them as mutually exclusive [Rijswoud, 2012, p. 20]. Although we approach public debates on expertise mainly from a relational point of view, we acknowledge that there are indeed substantive differences amongst different forms of expertise.

New expert groups include experience-based experts, "field experts" [Setälä and Väliverronen, 2014; Grundmann, 2017] and "lifestyle experts" [Lewis, 2010]. While not always disputing the knowledge and instructions provided by professional science-based experts, they challenge the knowledge basis and rhetoric of expertise. Field experts, including various nutrition therapists, sports instructors, public health nurses and personal fitness trainers, are "grassroots" experts on healthy living. Drawing both from scientific knowledge and experience-based expertise, field experts have acquired an important role in public debates on food and health [Setälä and Väliverronen, 2014; Väliverronen, 2016; Jallinoja, Jauho and Mäkelä, 2016; Huovila and Saikkonen, 2016]. Field experts are often active and skilled communicators using various tools and platforms. Thus, communication is an important part of their construction of expertise.

Gil Eyal [2020, p. 19] sums up this contestation of expertise from a relational perspective: "(E)xpertise is a not a thing, not a set of skills possessed by an individual or even by a group, but a historically specific way of talking ... by a situation in which the number of contenders for expert status has increased, the bases for their claims have become more heterogeneous and uncertain, and the struggles between them have become more intense".

Skeptics of scientific expertise have often been defined as less educated, anti-science and driven by irrational fears and anxiety [e.g. Blume, 2006]. However, recent studies have shown that public concerns are diverse and complex and are 
not always anti-science [e.g. Fahlquist, 2018; Jauho, 2016]. For example, proponents of low-carbohydrate, high-fat diets do not necessarily promote anti-science perspectives, but their trust in the representatives of science is under trial [Jallinoja, Jauho and Mäkelä, 2016; Jauho, 2016].

The proliferation of new types of actors with varying epistemic authority also has effects on the status and authority of scientists as public experts [Peters, 2008]. The institutional interlocking between science and the media has also become tighter in late modern societies. The media have increasingly become a source through which other social institutions gain public legitimacy and to whose practices scientists need to adapt when consulted in an expert role [Weingart, 1998; Rödder and Schäfer, 2010; Väliverronen, 2021]. Hence, public visibility has become a central channel of recognition as an expert authority, so much so that the term "media-derived authority" has been coined from Weber's classical typology [Herbst, 2003].

In this article, we approach the expansion of expertise in our specific case as networked expertise. Networked expertise refers to the "collective form of expertise in public controversy contexts" and to "formations of heterogeneous alliances between different kinds of experts and citizens" [Allgaier, 2012, p. 301]. In the pandemic situation, under conditions of uncertainty but with a high demand for information to guide action, established institutional borders are perceived as too rigid and there emerges calls for new ways of organising knowledge production as well as new types of expertise claims. This highlights expertise as a public process, where the credibility of expert performance is constructed and evaluated [Limoges, 1993].

\section{COVID-19 epidemic in Finland}

Initially, the epidemic was considered a distant occurrence located in a remote province of China. It became more tangible when the first case in Finland, a Chinese tourist visiting Lapland, was diagnosed on 29 January 2020. The outbreak in northern Italy, a popular tourist attraction for Finns, brought the epidemic closer. The first cases started to emerge, and on 1 March, 130 pupils were put into quarantine in a school in Helsinki, the capital of Finland. The number of diagnosed cases started to rise rapidly. On $16 \mathrm{March}$, the government declared a state of emergency, which closed schools and government-run public facilities such as museums, stipulated actions concerning critical medical infrastructure and introduced assembly prohibitions as well as quarantine measures for returning citizens and permanent residents. After the first COVID-19 casualties, this was followed on 27 March by travel restrictions and the closing of the southern and most populated Uusimaa region to non-essential traffic in order to prevent the spread of the epidemic.

Due to the fall in the number of new diagnosed cases, hospitalizations and deaths, these measures were gradually dismantled, starting with the lifting of the national travel restrictions on 15 April. This was followed by the opening of some public facilities (e.g. libraries) on 4 May and schools on 14 May. At the time of writing (the middle of June), the majority of the lockdown restrictions are no longer in place and the vital statistics are good, but the mood is expectant, with the possibility of another epidemic wave looming. 
In the end of June, there were a total of 328 deaths associated with COVID-19 in Finland. Tests had been done on 237,500 people, and the number of reported cases was 7,191 . In relation to the total population of Finland $(5,543,233)$, the overall incidence of cases is 130 cases per 100,000 people [Finnish Institute for Health and Welfare, 2020]. Thus, so far, Finland has managed the epidemic fairly well, similarly to other Nordic countries, Norway, Denmark and Iceland, and much better than Sweden, which adopted a different strategy related to COVID-19.

However, despite the relative success, Finnish health authorities - represented by the Finnish Institute for Health and Welfare, Finland (THL) and the Ministry of Social Affairs and Health issues (STM) in Finland - were often questioned during the epidemic.

\section{The context of health expertise}

Previously, the level of trust in science and expert institutions in Finland had remained one of the highest in the world [e.g. Wellcome Global Monitor, 2018; Finnish Science Barometer, 2019]. Science, technology and higher education projects have been relatively harmonious and mainly expert-driven in Finland, and they have received little critical public debate compared to that in many other European countries [Väliverronen, 2004; Väliverronen, 2006]. For instance, according to international comparisons, Finns are clearly more positive about vaccinations than the European average [European Commission, 2019; Wellcome Global Monitor, 2018]. One reason for this is the high level of trust in national institutions.

Central public health institutions in Finland include the THL, the STM, a number of NGOs such as patient organizations, and university departments conducting research in the fields of epidemiology, public health and medicine. THL provides decision-makers with information on health and welfare, and its representatives hold several positions on the central advisory boards and councils in the field [Late, 2014]. THL's parent ministry is the Ministry of Social Affairs and Health (STM).

THL and its representatives gain wide media publicity with respect to various public health issues, such as healthy eating, vaccinations and alcohol and drug policy. But in connection to these issues, THL has repeatedly come under criticism in the media. For example, either its recommendations on diet, alcohol consumption and vaccinations have been interpreted as too patronizing, usually by industry or by those promoting more liberal policies, or its researchers have been accused by citizen-activists of being lapdogs of the food industry or Big Pharma [on the latter Jauho, 2016].

A survey amongst Finns showed that in April 2020, 56\% of Finns considered that THL had succeeded very well or fairly well in managing the COVID-19 epidemic. A fifth of the respondents considered that THL had succeeded very or fairly badly in "managing the corona crisis" [Jallinoja and Väliverronen, 2020], while 69\% agreed somewhat or fully that amongst the most trustworthy experts in predicting and governing the corona epidemic are the representatives of THL. 
Our main data comprises of Finnish language Twitter discussions around THL and COVID-19 in the spring of 2020. Our empirical material for this study is extracted from a database of a commercial social media data analytics company, Mohawk, which extensively harvests public Finnish social media discussion at a rate of approximately 500,000 new messages per day [Pöyry et al., 2018]. As our focus was on the forms of public expertise, we decided to focus on Twitter, which is known to be the most central social media platform for political discussion and acts of communication aiming to influence political processes and public discussions [see Marttila et al., 2016; Nelimarkka et al., 2020; Vainikka and Huhtamäki, 2015], or to challenge and criticize the authorities [Ojala, Pantti and Laaksonen, 2019]. Further, it has become an important arena for communicating science to wider audiences and creating more impact for research [e.g. Darling et al., 2013; Haustein et al., 2016] as well as engaging citizens to public debates on issues related to science and technology [e.g. Su et al., 2017; Jahng and Lee, 2018].

Methodologically we build on a combination of online observation, social media data analysis and text analysis of the message contents. Our social media data collection was preceded with an intensive period of observing the public Twitter discussion around the Finnish coronavirus policies and measures by the two first authors. During March-May 2020 we held frequent peer briefing sessions to discuss our observations and notes concerning the ways how health authorities were criticized and what forms of alternative expertise were present in the online discussions.

Among the main voices and actors challenging the expertise of health authorities were opposition politicians, entrepreneurs, technology experts, as well as some scientists, physicians and a varying group of activated lay people. We also followed the main arguments in this critique and alternative policies in dealing with the pandemic. Most of these critiques favoured stronger measures in controlling the epidemic, thus suppression instead of mitigation. In our peer briefing sessions we identified three typical forms of critique targeted to the health authorities: 1) critique that contrasted the free circulation of ideas and insights in a liberal society with the outdated and bureaucratic processes of the health authorities; 2) critique that focused on epidemiological models, data science procedures and the related technical understanding and competence of the authorities, and 3) critique that promoted and advocated for authoritarian solutions and strict lockdown measures to fight the virus. In our further analysis, we decided to focus on the first two forms of criticism, since they both promoted a proactive role of the communicating 'experts' and their networking instead of merely pointing out solutions from other countries like the authoritarians.

Guided by these insights, we used the search feature of Twitter as well as the search interface of the Mohawk database. First, we started by exploring the direct commentary received by THL by browsing through messages that had mentions of THL or its Twitter account, @THLorg. Between 1 January and 16 June 2020, this query resulted in 124,143 tweets in total. Second, we filtered the data to exclude retweets, which left us with 64,388 unique messages. Next, we used poster follower counts to include only those with 50 followers or more, which limited our dataset to 48,459 tweets. By doing this, our analysis was focused on the most prominent Twitter users who already had gathered followership and status on the platform. 
Next, we did further qualitative explorations of the data to focus on two prominent forms of networked expertise: approaches based on liberalism and approaches building on data science and techno-solutionism. To explore the thematic discussions in more detail, the original dataset was further filtered using keyword searches. To investigate the liberalist claims, we started browsing through the data using certain prominent advocates of this approach, identified during the initial observation period, as our starting point. Next, we analysed the main topics and sources of critique used in their networks. To do this, we used the URLs of original tweets, provided by Mohawk, to explore the tweets in the context of their discussion threads.

For the discussions focused around data, technology and models, we queried the dataset with the words "data" OR "model", which resulted in 2,632 tweets in total. This subset was then analyzed in chronological order. For both subsets of data, the main topics and sources of critique were analyzed while reading through the data in chronological order.

The identified topics and actors were again discussed in a peer briefing session by all the authors.

In the following analysis section, we first discuss the public criticism of Finnish authorities' COVID strategy on a more general level, and then we explore the groups or coalitions which questioned the expertise of THL. We will particularly focus on two coalitions, which we call the liberalists and the data-solutionists. They not only criticized the established health expertise but also promoted an alternative form of expertise, which we call "networked expertise". First, we identify the main source of criticism and its premises, and secondly, we analyse the nature and motivations of alternative expertise. For research ethical reasons, all tweeter names and handles are removed from the excerpts presented in the analysis below. All examples have been translated from Finnish to English by the authors.

Analysis: questioning the established health expertise
During the corona crisis, the established health expertise, especially the THL, became increasingly contested. Also, the Ministry of Social Affairs and Health (STM) and the centre-left government were targeted by the critics, but here we chose to focus on THL, which is mainly responsible for advice on the control of the epidemic.

While THL itself was clearly the most active user in our full Twitter data with 1,495 original tweets, in the list of ten most active tweeters all others are individual users. Based on their profiles, six of these ten have tweeted extensively and almost exclusively about corona-related issues, with over 250 tweets each in our query.

One of the main differences between THL and its critics - both liberalists and data-solutionists - was rooted in the suppression vs. mitigation debate on COVID-19: whether the goal should be to stop the spread of the virus and to eliminate the virus, or just to slow down the epidemic. THL and the Finnish government favoured mitigation of the epidemic, arguing that in the case of global pandemic, total suppression was not an option. Further, THL argued that the social and economic costs of suppression would be too high. The critics, however, claimed that suppression of the epidemic was the best option. Important in their 
argumentation was the report by the COVID-19 experts of Imperial College London [Walker et al., 2020], published 16 March 2020 , which favoured suppression. Thus, the critics supported a decision by the government of a lockdown based on legislation of a "state of emergency" which entered into force on 17 March 2020. However, the critics continued to demand stricter measures even after the lockdown.

In the beginning of May, the Finnish government adopted a so-called hybrid strategy to manage the COVID-19 crisis. The measures proposed by the government aimed to prevent the spread of the virus in Finland, to safeguard the capacity of the healthcare system and to shield and protect people, especially those most at risk. The aim of this strategy was to curb the epidemic effectively while minimizing the adverse impact on people, businesses, society and the exercise of fundamental rights.

The hybrid strategy was questioned by some experts, who had earlier established a website called Eroonkoronasta.fi (Get rid of coronavirus). This letter was signed by experts in health and biomedicine, economics, mathematics, biology and education, amongst others, but not in epidemiology. This network was influenced by Endcoronavirus.org, an international network led by Yaneer Bar-Yam, the founder of the independent American think tank, the New England Complex Systems Institute (NECSI).

\section{The liberalist critique}

A prominent stream of critique against THL and the STM in our data was one advocated by liberalists. They had criticized THL previously for bureaucracy and old-fashioned policies, most notably on alcohol research and policy. Related to the pandemic, their critique was based on the assumption that Finnish health authorities had underestimated the COVID-19 disease in the beginning and had acted too slowly to curb the epidemic. This was causing harm to the economy.

Following the corona for a few weeks: THL is lagging far behind. One country at a time makes the same mistakes. Europe is responding faster (11 March 2020)

Yes, THL is the most effective player at the moment to destroy trust in the Authorities. Otherwise, it is not easy to beat online cops. (8 March 2020)

THL fails in assessments and actions, matters are silenced, documents are declared secret, Authorities hide behind each other's backs. Not like that, really not like that. Where are those now who laughed at "amateur virologists"? \#koronavirus (25 March 2020)

In this critique, statements and actions of international actors were mobilized as support. One of the main proponents of the liberalist critique was Juho Romakkaniemi, president of the Central Chamber of Commerce, who tweeted actively on the issue and also appeared as a commentator on TV and in newspapers.

The European Office of Communicable Diseases and most EU member states have ended up with faster preemptive measures than, for example, THL and the Finnish government have so far... Those who preach for blind faith and "yes THL knows better" can go on their own. (15 March 2020) 
Many tweeters made a reference to Finnish alcohol policy, which has been a politically sensitive issue in Finland. Finnish alcohol policy is based on comparatively strict regulations, similar to other Nordic countries, Sweden, Norway and Iceland [Karlsson et al., 2020]. Thus, the liberalist discourse continued earlier critiques of health advice and regulations proposed by the THL experts. In the public discourse on COVID-19, the mitigation strategies of the pandemic were connected to the strategies of alcohol policy:

\begin{abstract}
THL on a very moderate reform of the Alcohol Act: Everyone dies! THL on a potentially global pandemic: no worries. Hasn't this farce already been seen? Money off the idle propaganda organization \#THL! \#alcohol \#propaganda \#coronavirus (28 January 2020)

A megalomaniac epic failure by THL in \#alcohol law case, predicting growth and death, the opposite happened. That was just politics. So, it's pretty good to say that someone might have lost the trust. \#corona (7 March 2020)
\end{abstract}

One of the main proponents of alternative expertise was Mikael Junger, a well-known figure in Finland, the former CEO of the Finnish Broadcasting Company and former party secretary of the Social Democrats, who had later been involved in establishing a new political movement called Movement Now, which is defined as an "economically liberal social movement".

Funny comment. My idea of using crowdsourcing to fight the corona is reportedly the dumbest tweet ever... (13 March 2020)

This lay people vs. experts' discussion of corona follows the age-old discussion of generalists vs. specialists. The past 20th century was dominated by specialists, the 21 st century by generalists. Personally, I would say that both are needed, wisdom is in their cooperation. (15 March 2020)

The views of non-experts are important in social media because the enlightened social media activist combines his own observations with the views of the experts he encounters and forms the data into an individual body of knowledge. When 100 people do this, the ensemble is often very apt. Wisdom of crowds. (12 March 2020)

Jungner and some other liberalists not only criticized THL for old-fashioned expertise and wrong mitigation strategies but proposed alternative expertise based on lay knowledge and crowdsourcing. According to them, a significant amount of the information needed to manage the epidemic already exists, and most importantly, everyone can participate in finding and structuring it. The aim would therefore be to mobilize lay experts to gather and process the necessary information. The role of companies was also central in this activity.

"Lay expertise" [e.g. Wynne, 1998] usually refers to the practical skills of those considered lay people, thus, non-professionals with a lack of the credentials of expertise. Compared to formalized knowledge presented by scientific and professional experts, it refers to practical, hands-on knowledge in concrete contexts.

However, the latter quote also resembles something that Collins and Evans, in their normative theory of expertise, define as interactional expertise. According to Collins and Evans [2007], interactional experts are those who have undergone "enculturation within a linguistic community" of scientific experts and who are 
thus able to communicate with those experts and mediate expert knowledge. In the above, the commentator clearly argues that social media activists are not just those who "google fluently" but are those who have more or less internalized the discourse of expert knowledge.

Liberalists particularly criticized the reluctance of THL to increase testing as a means of controlling the spread of the epidemic. The critics argued that strong testing would be a good way to open up society and make the wheels of the economy spin again. Private health companies offered their testing capacity. Further, liberalists demanded a recommendation of the use of face masks and particularly criticized the STM, which did not see it necessary to make a recommendation for masks. Again, the liberalists argued, the face masks would be important for opening up the society more quickly.

This has been quite incomprehensible. STM and THL have not taken help and resources from companies in the crisis. Private health giants nervous for the Ministry of Social Affairs and Health - "We could do 4,000 corona tests a day, but help is not welcome" (7 April 2020)

Those critics favouring suppression instead of mitigation often referred to countries such as South Korea, New Zealand, Australia, Austria, Greece and Iceland, which had managed to control the epidemic. They warned about the looming economic crisis if the epidemic was not totally suppressed.

\section{Data-solutionist critique}

Another prominent stream of critique we identified was based on techno-utopianist and data-solutionist visions. The most active commenters in this stream were mostly non-academics: coders and data scientists, also accompanied by a few statisticians, a population science professor and a zoonotic disease researcher. Data-solutionists shared many of the critical remarks towards THL and STM made by liberalists and crowdsourcers. They too favoured a stricter strategy and suppression of the epidemic instead of mitigation, and they advocated the use of masks in prevention. However, their alternative was not so much lay expertise as extended epidemiological expertise, based on transparency, open data and models, a sharing of knowledge and the extensive use of data science and visualizations. They shared the argument made by liberalists that the epidemiological knowledge of THL was old-fashioned, that THL was relying on biased, outdated information and jury-rigged models based on the influenza virus instead of utilizing recent data and AI-powered predictions.

It is strange that THL could not take the WHO numbers seriously but built its model on $10 \times$ more optimistic numbers. "We are well prepared" messages while numbers are drawn on the basis of a self-constructed over-optimistic model is irresponsible. (25 March 2020)

Unfortunately, the perception of the health Authorities = @THLorg@mika_salminen is false and erroneous and is not based on research data or data that is abundantly available from the world about the \# COVID19 epidemic and its spread. (29 April 2020) 
The criticism was based on the assumption that the threat of COVID-19 was much more severe than THL and the ministry were presenting. In particular, the epidemiology model publicly released by THL on March 17 with an infection fatality rate of $1 \%$ received constant criticism. A frequent argument was that anybody with sufficient skills to wrangle existing data from China and then Italy could have predicted the situation in Finland already in January. Some commenters pointed out that instead of using in-house experts, THL should also reach out to mathematicians and other experts in quantitative modelling.

Claims that the effects of corona could not be predicted are largely false. Precedents and data were plentiful even before corona arrived in Finland, but everything was ignored by the [@PrimeMinister] and @THLorg. (26 March 2020)

Now listen to statisticians, mathematicians, and other quantum modeling experts, and not just @THLorg or [@ Ministry of Health]. In Illinois, when 25 cases were identified, the governor declared a \# state of emergency... (12 March 2020)

Indeed, in the discussions, mathematical terms and knowhow were frequently emphasized. Commenters questioned the mathematical expertise at THL and requested detailed information about the formulas and parameters used in THL's models. International sources, like the Imperial College report or reports on government actions in Singapore and South Korea were cited. Further, commenters based their suppression strategy on international examples, denying the importance of national differences argued by THL. Several commenters made ironic remarks about how THL was arrogant and thought it knew better than more qualified international experts.

A pertinent demand was that all data and calculations related to the COVID-19 outbreak should be made open and accessible. First requests calling for public epidemiology models and open data were presented immediately after the first COVID-19 case was diagnosed in Finland on 29 January. Throughout the data, the commenters in this stream connected the openness of data and models to the trustworthiness and accountability of THL. Practices of open science and reproducibility were commonly evoked, both by people with academic credentials and by laypeople. In April particularly, some commenters started directly accusing THL of hiding information and their models, accompanied by the claim that THL was pushing their own agenda - either steered by political views, the vaccine industry or the strategy of herd immunity.

Distrust is sown by only one party and it is THL that does not base its snapshot on open information. But conceals its model, parameters used, assumptions, and source references. (4 May 2020)

"The British have based their model on real research and published it. It is made available and transparent. I don't know where THL bases its assessment. It's hard to trust what isn't visibly justified," says @user \#operation science \#democracy. (25 March 2020)

This criticism resulted in concrete action. In mid-May, the openness-advocating NGO Open Knowledge Finland made an official information request to THL: 
OKFI has sent a request for information to the National Institute for Health and Welfare (THL) on the source codes for epidemic calculations. The publicity of the source code of epidemic calculations is a significant precedent for the interpretation of the Publicity Act. (13 May 2020)

Besides open data, the role of data was accentuated in other ways too. Data was depicted as the ultimate means to find truth, the right models and correct ways to act in the crisis. Commenters were worried about the outdated numbers published by THL and too low a number of COVID-19 tests and hence, a false understanding of the situation. As one commenter put it, "the infectious disease registry is not functioning so we have a datastrophe in our hands" (30 March 2020, emphasis added). Also, in these comments, comparisons to other countries were constantly made, with the main claim being that the Finnish authorities should take advice from the existing data and models made elsewhere. Further, commenters were worried that as testing was not being widely done, there would be no data for future uses either.

While most of the discussions focused on data and modelling work to critique, some presented calls for action and exhibited a proactive approach to the situation. It was suggested that making coronavirus data publicly available would allow those with skills to build their own models and apps - thus, also promoting ideas of crowdsourcing similar to the liberals. When the data on infections by region was released by THL on 27 March, the data-solutionists indeed started producing their own models.

What is notable is that Markku Peltonen, also a research professor working at THL, started in late March to publish his own daily rogue visualizations of the disease situation in Finland. These visualizations were frequently praised by the online discussants and were also jointly developed further in conversations. It seems that the responsive, dialogical communication by Professor Peltonen worked in particular to imbue his visualizations with credibility and trustworthiness - by making a stark contrast with the allegedly slow communication by THL.

Another form of data that figured in the discussion of data-solutionists was contact tracing data. Already in March, tweeters started concretely discussing how a COVID-19 tracing app should be implemented, how existing apps and data could be used in the tracing and how that data could be used to safely open up society. The potential solutions included, for example, existing geolocation data from teleoperators, pre-collected health data and a parking app. Privacy and data protection issues were also covered. The undertone in these discussions was that THL lacked knowledge of the modern technologies and needed to be guided by real experts.

Extensive \#corona testing would benefit, but resources are not enough. Officially the figures for those affected cover only a fraction. Could online services like \#OmaOlo be used in epidemics? Voluntary reporting of symptoms / asymptomatic and data analysis. (15 March 2020)

I am not an expert in the field, but could you imagine that the Easypark app could be customized into an app with which personal data could be collected easily, simply add the fever level e.g. 39.0 and send. Everything is saved immediately and in several days. (21 March 2020) 
Discussion:

networked

expertise as an

alternative to the

health

establishment
In this study, we identified and explored the communication patterns and argumentation of two alternative networked expert coalitions that became active on social media during the coronavirus pandemic in Finland in spring 2020: economic liberalists and data-solutionists. Despite the differing ideological starting points, both groups advocated for stricter restrictions, albeit somewhat incoherently, accompanied by hopes for lean, less bureaucratic governance.

The liberalists foregrounded lay knowledge and crowdsourcing in their approach to expertise. According to them, the key information to manage the epidemic was already available, and the problem was more how to gather and structure it in the most efficient and beneficial way. Here, each enlightened citizen could participate by offering his or her resources to the common task. This take on lay knowledge highlights less the lived experience of a condition or situation but rather, familiarity with science and society, perhaps reflecting the liberalists' backgrounds as persons with influential positions in society.

For the liberalist critique, lay knowledge points to a strategy where active citizens follow scientific and public discussions in different channels and, based on the gathered insight and their societal experience, then offer their opinions, feeding them back into the ongoing discussion. This is not only framed as participating in public discussion as an active citizen with a voice but is thematized in relation to expertise as a valid position which expands its traditional boundaries. Previous research on lay knowledge vis-à-vis expertise has stressed the lived experience of participants [e.g. Wynne, 1998], yet in this case, lay knowledge engaged directly with science [see also Jauho, 2016; Fahlquist, 2018].

Another trend of criticism, data-solutionism, was based on techno-utopianist views, data science and $\mathrm{AI}$ as well as on open data and science approaches. Some of the tweeters following this line of argumentation openly questioned the expertise of THL when it came to mathematical modelling. Some worked to undermine the credibility of THL through their tweets, while others offered their own solutions and built their own models and visualizations to analyse the situation in Finland. An overarching argument was that with existing data (also international), state-of-the art data science models and proper predictive models, the disease situation could have been more precisely predicted and mitigation strategies aligned accordingly. In order for this to happen, precise data is needed: real-time data from the cases in Finland as well as tracing apps to follow the spread of the virus.

A fundamental undertone of this form of networked expertise was the alleged lack of openness and transparency of THL's work. Data-solutionists criticized THL for hiding its models, and they demanded openly accessible data sets and transparency of analytical principles and procedures. These demands were advocated both in the name of transparency and accountability of a governmental actor but also to afford the realization of the techno-solutionist visions, such as tweaking the epidemiology models following the practices of open source science and software development.

From the perspective of contested expertise, the data-solutionist argumentation is not an example of field expertise [Setälä and Väliverronen, 2014] or lay expertise (as for liberalists), but rather of epistemic trespassing, where experts in one field start commenting on and working with problems in another field of expertise 
[Ballantyne, 2019]. In this case, it seems the expertise building on mathematical and technical skills such as predictive modelling is seen to work as a transferable skill which also transfers expertise or at least, provides a superior position from which to criticize other fields, using somewhat similar methodology regardless of the topical expertise.

In terms of the science-policy relationship, the data-solutionist position seems to involve a somewhat naive idea of context-free knowledge. The position implies that if only institutional borders and bureaucratic constraints were removed, the best ideas and arguments could flourish. Such an outlook actively discounts the institutional context of knowledge production and the situated and political nature of knowledge claims. For data-solutionists, such contextual factors are only barriers to free science and are not unavoidable elements of all scientific activity.

Table 1. Contesting of health establishment and the promotion of alternative expertise.

\begin{tabular}{|l|l|l|}
\hline & Liberalists & $\begin{array}{l}\text { Data-solutionists \& } \\
\text { open knowledge advocates }\end{array}$ \\
\hline $\begin{array}{l}\text { Targets of } \\
\text { criticism }\end{array}$ & $\begin{array}{l}\text { THL, STM } \\
\text { Old-fashioned } \\
\text { definitions of expertise }\end{array}$ & $\begin{array}{l}\text { THL, STM } \\
\text { Old-fashioned definitions of expertise } \\
\text { Non-public data and models }\end{array}$ \\
\hline Basis of criticism & Economic liberalism & Data science, open knowledge, ICT \\
\hline $\begin{array}{l}\text { Alternative } \\
\text { evidence }\end{array}$ & $\begin{array}{l}\text { International } \\
\text { examples: WHO }\end{array}$ & $\begin{array}{l}\text { International examples: } \\
\text { Imperial College }\end{array}$ \\
\hline $\begin{array}{l}\text { Alternative } \\
\text { expertise }\end{array}$ & $\begin{array}{l}\text { Lay expert } \\
\text { Enlightened social } \\
\text { media activist } \\
\text { Wisdom of crowds }\end{array}$ & $\begin{array}{l}\text { Experts from other fields of science } \\
\text { than epidemiology: data science, } \\
\text { open data, ICT industry and start-ups }\end{array}$ \\
\hline $\begin{array}{l}\text { Means and } \\
\text { exemplification }\end{array}$ & $\begin{array}{l}\text { Crowdsourcing } \\
\text { COVID-19 tracking apps }\end{array}$ & $\begin{array}{l}\text { Open data and science, source codes } \\
\text { Data visualizations }\end{array}$ \\
\hline
\end{tabular}

If we put these battles of COVID-19 expertise into a larger social context, we enter the recursive processes of the "scientization of politics" and the "politicization of science" [Weingart, 2003], which "reinforce and entangle one another in an unstable, crisis-prone mixture" [Eyal, 2020, p. 97]. The roots of this development lie in the development where science and technology are mobilized to solve not only medical, social and environmental risks, such as pandemics or environmental threats, but also the legitimation problems of the state. State research institutes, such as THL, are at the same time scientific institutions and governmental organizations involved in the decision-making on health risks. In our case, THL was also the main organization on whose calculations and expert advice the Finnish government based its decisions about the control and mitigation of the epidemic. This dual role makes these expert organizations prone to politicization and public questioning. In our analysis, we showed how this public questioning was partly rooted in the previous critique of THL's role in Finnish alcohol policy (liberalist critique) and was partly related to more recent kinds of legitimation problems, such as transparency, openness and style of communication (data-solutionist critique).

Further, both critical discourses promoted crowdsourcing and networked expertise, thus arguing for more inclusive - instead of exclusive - politics of expertise. According to liberalists, "lay experts", as well as crowdsourcers and mediators of 
professional knowledge were capable of understanding and speaking the same language with professional experts, and thus could contribute to a better management of the epidemic. Of course, the liberalists were also eager to promote private industries, particularly the input of health care companies, as part of the solution to the crisis. Data-solutionists, on the other hand, wanted to extend the circles of legitimate expertise beyond epidemiology to other fields of science, such as data science. They also extended relevant expertise beyond professional science to various data professionals.

These debates point out that the understanding and managing of social problems, such as the COVID-19 epidemic on a national level, have evolved beyond scientific and technical expertise: "(I)t is no longer the case that scientific advice is a resource that is only available to government officials or other particularly well-equipped players" [Allgaier, 2012, p. 300]. Our case demonstrates that particularly in crisis situations like a pandemic, the public questioning of established and credentialized expertise evokes the promotion of alternative forms of expertise based on networking between different actors - afforded by online communication platforms that help them convene. Further, it seems that responsive and dialogical science communication is important in building trust and credibility.

Thus, the above debates over expertise should not be interpreted simply as a mistrust of science or a mistrust in professional expertise, as the common post-truth or death of expertise discourses assume. Instead, they point to the increasing politicization of science and expertise. The battles over "who is a trusted expert" and "what is trusted expert advice made of" have become a commonplace. This development should not necessarily be interpreted as a decline in or "assault on science and expertise". Rather, it could be seen as attempts to move the signposts of what constitutes (relevant) expertise for different issues and situations, questioning the limits and status of traditional expertise. Of course, this public questioning sometimes uses unjustified and false claims, perhaps also evoking conspiracy theories, but it should not be evaluated only by obvious misunderstandings or as pure fake news.

This study is limited by its national and technological context: our data only essentially describes the situation in Finland, and only covers the discussions and forms of criticism prevailing on Twitter. Other platforms and other national contexts might reveal other discourses of criticism targeted towards the health authorities, for example arguments in favor of lifting the restrictions. However, the digital communication practices related to the development of networked expertise we accentuate in this article are not dependent on the particular context or content of the communication, but rather more general practices made possible by the networked communication technologies. We suggest that future research should continue exploring the ways in which the online platforms are used in the construction of different forms of expertise and expert communication. 
Allgaier, J. (2012). 'Networking expertise: discursive coalitions and collaborative networks of experts in a public creationism controversy in the U.K.' Public Understanding of Science 21 (3), pp. 299-313. https://doi.org/10.1177/0963662510383385.

Ballantyne, N. (2019). 'Epistemic trespassing'. Mind 128 (510), pp. 367-395. https://doi.org/10.1093/mind/fzx042.

Bildtgård, T. (2008). 'Trust in food in modern and late-modern societies'. Social Science Information 47 (1), pp. 99-128. https://doi.org/10.1177/0539018407085751.

Blume, S. (2017). Immunization. How vaccines became controversial. London, U.K.: Reaktion Books.

Blume, S. (2006). 'Anti-vaccination movements and their interpretations'. Social Science \& Medicine 62 (3), pp. 628-642. https://doi.org/10.1016/j.socscimed.2005.06.020.

Castell, S., Charlton, A., Clemence, M., Pettigrew, N., Pope, S., Quigley, A., Shah, J. N. and Silman, T. (2014). Public attitudes to science 2014: main report. URL: https://assets.publishing. service.gov.uk/government/uploads/sys tem/uploads/attachment_data/file/348830/bis-14-p111-public-attitude s-to-science-2014-main.pdf.

Chen, E., Lerman, K. and Ferrara, E. (2020). 'Tracking social media discourse about the COVID-19 pandemic: development of a public coronavirus Twitter data set'. JMIR Public Health and Surveillance 6 (2), e19273. https://doi.org/10.2196/19273. arXiv: 2003.07372.

Collins, H. (2014). Are We All Scientific Experts Now? Cambridge, U.K.: Polity Press.

Collins, H. and Evans, R. (2007). Rethinking expertise. Chicago, IL, U.S.A.: University of Chicago Press. https://doi.org/10.7208/chicago/9780226113623.001.0001.

Darling, E., Shiffman, D., Côté, I. and Drew, J. (2013). 'The role of Twitter in the life cycle of a scientific publication'. Ideas in Ecology and Evolution 6, pp. 32-43. https://doi.org/10.4033/iee.2013.6.6.f.

European Commission (2019). Europeans' attitudes towards vaccination. Special Eurobarometer 488. Directorate-General for Health and Food Safety, European Commission. URL: https://ec. europa.eu/health/sites/health/files/vacci nation/docs/20190426_special-eurobarometer-sp488_en.pdf.

Eyal, G. (2020). The crisis of expertise. Cambridge, U.K.: Polity.

Fahlquist, J. N. (2018). 'Vaccine hesitancy and trust. Ethical aspects of risk communication'. Scandinavian Journal of Public Health 46 (2), pp. 182-188. https://doi.org/10.1177/1403494817727162.

Finnish Institute for Health and Welfare (2020). Situation update for coronavirus. URL: https://thl.fi/en/web/infectious-diseases-and-vaccinations/what -s-new/coronavirus-COVID-19-latest-updates/situation-update-on-coro navirus.

Finnish Science Barometer (2019). A study of Finns' attitudes towards science and and their opinions on scientific and technical progress. English summary. Helsinki, Finland. URL: http://www.tieteentiedotus.fi/files/Sciencebarometer_201 9_23122019.pdf.

Giddens, A. (1991). Modernity and self-identity. Cambridge, U.K.: Polity Press.

Grundmann, R. (2017). 'The problem of expertise in knowledge societies'. Minerva 55 (1), pp. 25-48. https: //doi .org/10.1007/s11024-016-9308-7. 
Gunnarsson, A. and Elam, M. (2012). 'Food fight! The Swedish Low-Carb/High Fat (LCHF) movement and the turning of science popularisation against the scientists'. Science as Culture 21 (3), pp. 315-334.

https://doi.org/10.1080/09505431.2011.632000.

Haustein, S., Bowman, T. D., Holmberg, K., Tsou, A., Sugimoto, C. R. and Larivière, V. (2016). 'Tweets as impact indicators: examining the implications of automated "bot" accounts on Twitter'. Journal of the Association for Information Science and Technology 67 (1), pp. 232-238. https://doi.org/10.1002/asi.23456.

Herbst, S. (2003). 'Political authority in a mediated age'. Theory and Society 32, pp. 481-503. https://doi.org/10.1023/A:1025571226279.

Huovila, J. and Saikkonen, S. (2016). 'Establishing credibility, constructing understanding: the epistemic struggle over healthy eating in the Finnish dietetic blogosphere'. Health: An Interdisciplinary Journal for the Social Study of Health, Illness and Medicine 20 (4), pp. 383-400. https://doi.org/10.1177/1363459315595849.

Jahng, M. R. and Lee, N. (2018). 'When scientists tweet for social changes: dialogic communication and collective mobilization strategies by Flint Water Study scientists on Twitter'. Science Communication 40 (1), pp. 89-108. https://doi.org/10.1177/1075547017751948.

Jallinoja, P. and Väliverronen, E. (2020). 'Experts, authorities and citizens during the COVID-19 crisis'. Unpublished manuscript.

Jallinoja, P., Jauho, M. and Mäkelä, J. (2016). ‘Newspaper debates on milk fats and vegetable oils in Finland, 1978-2013: an analysis of conflicts over risks, expertise, evidence and pleasure'. Appetite 105, pp. 274-282. https://doi.org/10.1016/j.appet.2016.05.035.

Jasanoff, S. (2004). 'Ordering knowledge, ordering society'. In: States of knowledge: the co-production of science and social order. Ed. by S. Jasanoff. London, U.K.: Routledge, pp. 13-45. https://doi.org/10.4324/9780203413845.

Jauho, M. (2016). 'The social construction of competence: conceptions of science and expertise among proponents of the low-carbohydrate high-fat diet in Finland'. Public Understanding of Science 25 (3), pp. 332-345. https://doi.org/10.1177/0963662514558167.

Karlsson, T., Mäkelä, P., Tigerstedt, C. and Keskimäki, I. (2020). 'The road to the Alcohol Act 2018 in Finland: a conflict between public health objectives and neoliberal goals'. Health Policy 124 (1), pp. 1-6. https://doi.org/10.1016/j.healthpol.2019.10.009.

Kata, A. (2012). 'Anti-vaccine activists, Web 2.0 and the postmodern paradigm An overview of tactics and tropes used online by the anti-vaccination movement'. Vaccine 30 (25), pp. 3778-3789. https://doi.org/10.1016/j.vaccine.2011.11.112.

Late, E. (2014). 'Cultural and contextual shaping of scholarly communication'. Publishing and reading practices in Finnish state research institutes. Tampere, Finland: The University of Tampere. URL: http://urn.fi/URN : ISBN : 978-951-44-9625-7.

Lewis, T. (2010). 'Branding, celebritization and the lifestyle expert'. Cultural Studies 24 (4), pp. 580-598. https://doi.org/10.1080/09502386.2010.488406.

Limoges, C. (1993). 'Expert knowledge and decision-making in controversy contexts'. Public Understanding of Science 2 (4), pp. 417-426. https://doi.org/10.1088/0963-6625/2/4/009. 
Marttila, M., Laaksonen, S.-M., Kekkonen, A., Tuokko, M. and Nelimarkka, M. (2016). 'Digitaalinen vaaliteltta: Twitter politiikan areenana eduskuntavaaleissa 2015'. In: Eduskuntavaalitutkimus 2015: Poliittisen osallistumisen eriytyminen. Oikeusministeriön Selvityksiä ja julkaisuja 28/2016. Ed. by K. Grönlund and H. Wass. Helsinki, Finland: Oikeusministeriö, pp. 117-137. URL: http://urn.fi/URN : ISBN : 978-952-259-517-1.

National Science Foundation (2018). Science and engineering indicators 2018. Science and technology: public attitudes and understanding. URL: https://www.nsf.gov/statistics/2018/nsb20181/assets/404/science - and-technology-public-attitudes-and-understanding.pdf.

Nelimarkka, M., Laaksonen, S.-M., Tuokko, M. and Valkonen, T. (2020). ‘Platformed interactions: how social media platforms relate to candidate-constituent interaction during Finnish 2015 election campaigning'. Social Media + Society 6 (2). https://doi.org/10.1177/2056305120903856.

Nichols, T. (2017). The death of expertise: the campaign against established knowledge and why it matters. New York, NY, U.S.A.: Oxford University Press.

Nowotny, H. (2000). 'Transgressive competence: the narrative of expertise'. European Journal of Social Theory 3 (1), pp. 5-21. https://doi.org/10.1177/136843100003001001.

Ojala, M., Pantti, M. and Laaksonen, S.-M. (2019). 'Networked publics as agents of accountability: online interactions between citizens, the media and immigration officials during the European refugee crisis'. New Media \& Society 21 (2), pp. 279-297. https://doi .org/10.1177/1461444818794592.

Peters, H. P. (2008). 'Scientists as public experts'. In: Handbook of public communication of science and technology. Ed. by M. Bucchi and B. Trench. Abingdon, U.K.: Routledge, pp. 131-146.

Pöyry, E., Laaksonen, S.-M., Kekkonen, A. and Pääkkönen, J. (2018). 'Anatomy of viral social media events'. In: Proceedings of the $51^{\text {st }}$ Hawaii International Conference on System Sciences (Waikoloa Village, HI, U.S.A. 3rd-6th January 2018). U.S.A.: Hawaii International Conference on System Sciences. https://doi.org/10.24251/hicss.2018.272.

Rijswoud, E. (2012). 'Public faces of science: experts and identity work in the boundary zone of science, policy and public debate'. Ph.D. thesis. Nijmegen, The Netherlands: Radboud University of Nijmegen.

URL: https://hdl . handle.net/2066/91456.

Rödder, S. and Schäfer, M. S. (2010). 'Repercussion and resistance. An empirical study on the interrelation between science and mass media'. Communications 35 (3). https://doi.org/10.1515/comm.2010.014.

Setälä, V. and Väliverronen, E. (2014). 'Fighting fat: the role of 'field experts' in mediating science and biological citizenship'. Science as Culture 23 (4), pp. 517-536. https://doi.org/10.1080/09505431.2014.905526.

Sismondo, S. (2017). 'Post-truth?' Social Studies of Science 47 (1), pp. 3-6. https://doi.org/10.1177/0306312717692076.

Smith, T. W. and Son, J. (2013). Trends in public attitudes about confidence in institutions. Chicago, IL, U.S.A.: NORC, University of Chicago. URL: https://www . norc .org/PDFs/GSS\%20Reports/Trends\%20in\%20Confidenc e\%20Institutions_Final.pdf.

Su, L. Y.-F., Scheufele, D. A., Bell, L., Brossard, D. and Xenos, M. A. (2017). 'Information-Sharing and Community-Building: Exploring the Use of Twitter in Science Public Relations'. Science Communication 39 (5), pp. 569-597. https://doi.org/10.1177/1075547017734226. 
Tharoor, I. (9th March 2020). 'The coronavirus outbreak is making expertise great again'. The Washington Post.

URL: https://www.msn.com/en-ph/news/politics/the-coronavirus-outbrea $\mathrm{k}$-is-making-expertise-great-again/ar-BB10Vxm2?li=BBZAn2m.

Vainikka, E. and Huhtamäki, J. (2015). 'Tviittien politiikkaa — poliittisen viestinnän sisäpiirit Twitterissä'. Media \& viestintä 38 (3), pp. 165-183.

URL: https://journal.fi/mediaviestinta/article/view/62081.

Väliverronen, E. (2016). Julkinen tiede. [Public science]. Tampere, Finland: Vastapaino.

Väliverronen, E. (2004). 'Stories of the "medicine cow": representations of future promises in media discourse'. Public Understanding of Science 13 (4), pp. 363-377. https://doi.org/10.1177/0963662504046635.

- (2006). 'Expert, healer, reassurer, hero and prophet: framing genetics and medical scientists in television news'. New Genetics and Society 25 (3), pp. 233-247. https://doi .org/10.1080/14636770601032742.

- (2021). 'The mediatisation of science and the rise of promotional culture'. In: Routledge handbook of public communication of science and technology. Ed. by M. Bucchi and B. Trench. 3rd ed. Forthcoming. Routledge.

Walker, P. G. T., Whittaker, C., Watson, O., Baguelin, M., Ainslie, K. E. C., Bhatia, S., Bhatt, S., Boonyasiri, A., Boyd, O., Cattarino, L., Cucunubá, Z.,

Cuomo-Dannenburg, G., Dighe, A., Donnelly, C. A., Dorigatti, I., van Elsland, S., FitzJohn, R., Flaxman, S., Fu, H., Gaythorpe, K., Geidelberg, L., Grassly, N., Green, W., Hamlet, A., Hauck, K., Haw, D., Hayes, S., Hinsley, W., Imai, N., Jorgensen, D., Knock, E., Laydon, D., Mishra, S., Nedjati-Gilani, G., Okell, L. C., Riley, S., Thompson, H., Unwin, J., Verity, R., Vollmer, M., Walters, C., Wang, H. W., Wang, Y., Winskill, P., Xi, X., Ferguson, N. M. and Ghani, A. C. (26th March 2020). The global impact of COVID-19 and strategies for mitigation and suppression. WHO Collaborating Centre for Infectious Disease Modelling, MRC Centre for Global Infectious Disease Analysis, Abdul Latif Jameel Institute for Disease, Emergency Analytics and Imperial College London. https://doi.org/10.25561/77735.

Weingart, P. (1998). 'Science and the media'. Research Policy 27 (8), pp. 869-879. https://doi.org/10.1016/S0048-7333(98)00096-1.

- (2003). 'The paradoxes of expert advising'. In: Expertise and its interfaces. Ed. by G. Bechmann and I. Hronskzky. Berlin, Germany: Sigma, pp. 43-89.

Wellcome Global Monitor (2018). How does the world feel about science and health. London, U.K.: Wellcome Trust.

URL: https://wellcome.ac.uk/reports/wellcome-global-monitor/2018.

Wynne, B. (1998). 'May the Sheep Safely Graze? A Reflexive View of the Expert-Lay Knowledge Divide'. In: Risk, Environment and Modernity: Towards a New Ecology. Chapter 2. Ed. by S. Lash, B. Szerszynski and B. Wynne. London, U.K.: SAGE Publications Ltd, pp. 44-83. https://doi.org/http://dx.doi.org/10.4135/9781446221983.n3. University of Helsinki, Faculty of Social Sciences. His research interests include media theories, journalism and social studies of science. He has written extensively on science communication and environmental communication. Currently he leads the projects Public Expertise and Freedom of Expression and Mediating Expertise: public debates on health. E-mail: esa.valiverronen@helsinki.fi. 
Salla-Maaria Laaksonen (Dr. Soc. Sc.) is Postdoctoral Researcher at Centre for Consumer Society Research, University of Helsinki. She has published extensively on social media and organizational communication. Her current research focuses on how organizations are using data and machine learning methods and the use of digital and computational methods to study the hybrid media system.

E-mail: salla.laaksonen@helsinki.fi.

Mikko Jauho (Dr. Soc. Sc.) is University Researcher at Centre for Consumer Society Research, University of Helsinki. Working at the interfaces of science and technology studies, governmentality studies, sociology of health and illness and consumer research, his research focuses on the politics of public health and practices of personal health care as well as the links and frictions between these two levels. Currently he is finalising a project on the rise of the notion of lifestyle risk in health care. E-mail: mikko.jauho@helsinki.fi.

Piia Jallinoja is a Professor of Health Sociology at the Tampere University. She has published extensive on various health- and food-related phenomena from a sociological perspective, such as discourses on healthy lifestyle and lifestyle change, low-carbohydrate dieters, debates over dietary fats in the media, and the rise of veganism in the media. Currently she is leading a project analyzing established and emerging expert groups in the issues of nutrition, food and health. E-mail: piia.jallinoja@tuni.fi. and data-solutionists: redefining expertise in Twitter debates on coronavirus in Finland'. JCOM 19 (05), A10. https://doi.org/10.22323/2.19050210. 